\title{
Grouping in roe deer: an effect of habitat openness or cover distribution?
}

\author{
Cristina SAN JOSÉ, Sandro LOVARI* and Natalia FERRARI
}

\begin{abstract}
San José C., Lovari S. and Ferrari N. 1997. Grouping in roe deer: an effect of habitat openness or cover distribution? Acta Theriologica 42: 235-239.

Counts of roe deer Capreolus capreolus (Linnaeus, 1758) were conducted in the open fields of two reserves in Siena county (central Italy). Area A and area B were characterized by different indices of wood dispersion ( 0.8 and 1.6 respectively). Solitary roe deer were seen significantly more often in area B (open fields: $80 \%$ ) than in area A (open fields: $48 \%$ ). Males were significantly more solitary than females in both areas. Group size varied throughout the year, showing similar tendencies in both sexes and areas. The differences in deer concentration between areas appeared to depend on the distribution pattern of woodland more than proportion of open habitat.
\end{abstract}

Dipartimento di Biologia Evolutiva, Gruppo di Etologia e Ecologia Comportamentale, Universitá di Siena, Via Mattioli 4, 53100 Siena, Italy

Key words: Capreolus capreolus, grouping, cover, habitat

\section{Introduction}

Nearly all factors which may determine grouping in ungulates can be directly or indirectly associated to two main ecological correlates. Grouping may develop as an anti-predator behaviour of species living in open habitat (Jarman 1974) or as a consequence of the concentration of abundant food resources (Geist 1974). While members of groups forming under the pressure of predation risks tend to socially interact, those aggregating on rich food resources may not (Geist 1974).

It has been suggested that grouping in roe deer Capreolus capreolus (Linnaeus, 1758), a solitary living and forest dwelling species (Dzięciołowski 1979, Putman 1988, Ratcliffe and Mayle 1992), may be a direct consequence of population density (Bideau et al. 1985, Vincent and Bideau 1992), habitat openness (Kurt 1968, Maublanc et al. 1987), food availability (Zejda 1978, Maublanc et al. 1987) or habitat patchiness (Cibien et al. 1989).

The aim of our paper is to compare levels of association of roe deer in two neighbour areas with a high proportion of differently distributed dense wood cover, to assess the importance of cover dispersion for grouping.

* To whom reprints may be asked. 


\section{Study area and methods}

Two roe deer populations were studied in two areas of Siena county $\left(43^{\circ} \mathrm{N}, 11^{\circ} \mathrm{E}\right.$, at an altitude of 150 to 350 m a.s.1.), central Italy, from 15 June 1993 to 15 June 1994 (Fig. 1). Area A extended for 920 ha of thick Mediterranean oak wood Quercus pubescens with a dense understorey $(52 \%)$ and open meadows (48\%). Wood cover occupied uniformly the south-eastern half of the area (wood perimeter/ /wooded surface $=0.02$; index of wood dispersion $\mathrm{I}=\mathrm{s}^{2} / \bar{x}=0.8$, Krebs 1989: 76-77). Area B extended for 400 ha, mainly open fields $(80 \%)$, interspersed with oak woodlots for a total of $20 \%$. Wood cover was aggregated in patches (wood perimeter/wooded surface $=0.24 ; \mathrm{I}=1.6$; Fig. 1). Linear distance between areas $\mathrm{A}$ and $\mathrm{B}$ was $14 \mathrm{~km}$.

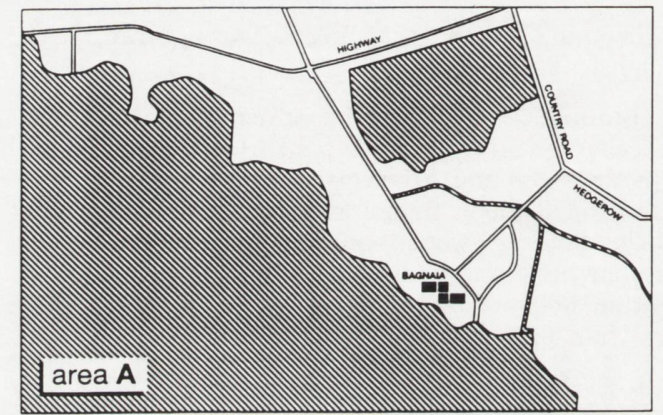

$\mathbf{N} \rightarrow$

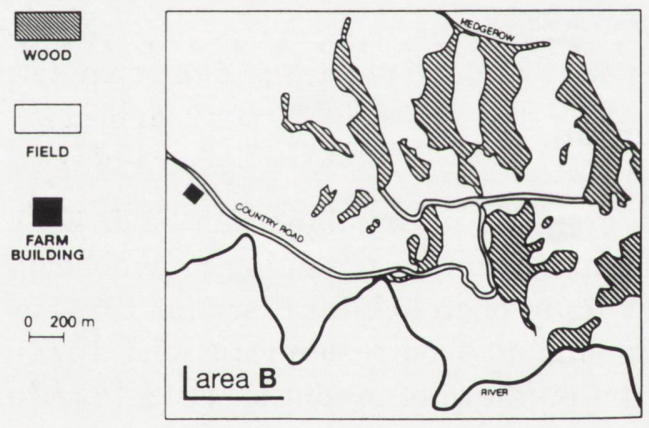

Fig. 1. Wood distribution in the study areas.

The mean temperature during the study period was $18.3 \pm 6.5^{\circ} \mathrm{C}$. Minimum temperature occurred in February $\left(-4.6^{\circ} \mathrm{C}\right)$ and maximum temperature peaked in July $\left(35.5^{\circ} \mathrm{C}\right)$. Precipitation (125 rainy days, in total) was $836 \mathrm{~mm}$ and occurred in all seasons. Snowfall never occurred throughout our study.

The calving season of roe deer in our study areas takes place normally in the second half of May and the first fortnight of June. The rutting season occurs from the middle of July to the middle of August. Deer density in 1994, estimated by diurnal drive censuses in the wood (Hoffmann 1976), was high in both areas: ca 37 deer/100 ha. The sex ratio (males: females) was $1: 1.1$ in both areas in the rut (4 counts in area A, 5 counts in area B). Free-ranging dogs, preying on deer, have been sighted in both areas. Both areas are game reserves, with similar hunting pressure (aimed at wild boar, pheasant and hare), from the end of September to the end of January. Moderate selective hunting of roe deer takes place in neighbour estates, after the rutting season.

Group size was recorded monthly. Standard counts (3-4 times/month, evenly spaced) were carried out in both study areas by car at sunset (Hoffmann 1976). All deer in the open fields were counted using binoculars $(9 \times 36$ and $20 \times 60)$. A group was arbitrarily defined as a set of animals ( 2 or more) within $50 \mathrm{~m}$ from one another.

Differences between proportions were tested for significance as suggested by Hald (1967). Correlations were evaluated through the Spearman rank correlation coefficient, whereas differences of group size between areas were tested by the Friedman ANOVA.

\section{Results}

Sightings of solitary individuals (irrespective of sex) were recorded more often in area $\mathrm{B}(25.5 \% ; n=1061$ deer sightings) than in area A $(19 \% ; n=2420$ deer sightings $)(Z=4.25, p<0.001)$. Males were significantly more solitary (area A: 
Area A

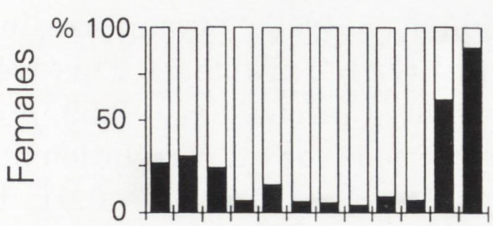

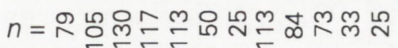

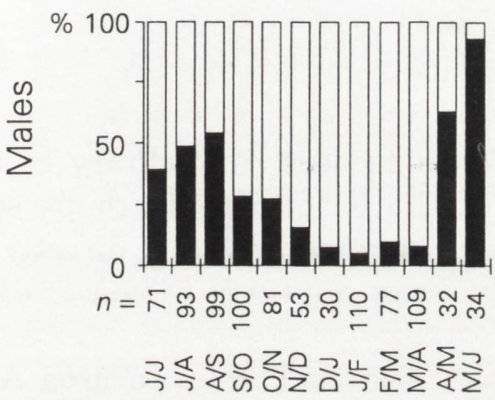

Area B

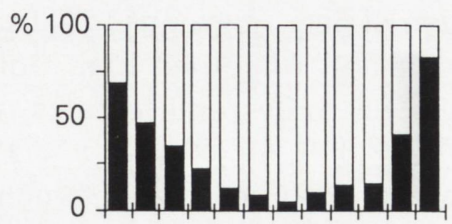

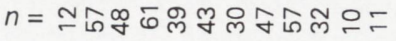

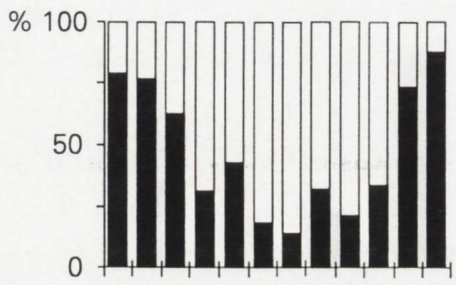

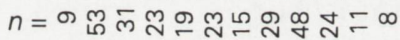

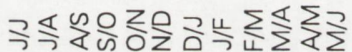

Fig. 2. Variation in the percentage of solitary males and females over the study period ( $n$ - number of deer).

$29.4 \%, n=889$ male sightings; area B: $44 \%, n=293$ male sightings) than females (area A: $17.2 \%, n=947$ female sightings; area B: $22.1 \%, n=447$ female sightings) (area A: $Z=6.23, p<0.001$; area B: $Z=5.91, p<0.001$ ). Males and females of area $B$ were more solitary than individuals of the same sex in area A (males: $Z=4.56, p<0.001$; females: $Z=2.13, p<0.05$ ). In both areas the greatest

Table 1. Monthly variation of group size in area A and B ( $n$ - total number of groups).

\begin{tabular}{|c|c|c|c|c|c|c|c|c|}
\hline \multirow[t]{2}{*}{ Period } & \multicolumn{4}{|c|}{ Area A } & \multicolumn{4}{|c|}{ Area B } \\
\hline & $n$ & $\bar{x}$ & SD & Max & $n$ & $\bar{x}$ & SD & Max \\
\hline Mid-June/mid-July & 41 & 2.87 & 1.18 & 6 & 6 & 2.33 & 0.81 & 4 \\
\hline Mid-July/mid-August & 66 & 2.64 & 2.64 & 7 & 22 & 2.32 & 0.65 & 4 \\
\hline Mid-August/mid-September & 83 & 2.85 & 1.33 & 10 & 28 & 2.57 & 0.92 & 5 \\
\hline Mid-September/mid-October & 94 & 3.23 & 1.78 & 12 & 39 & 2.76 & 1.25 & 8 \\
\hline Mid-October/mid-November & 73 & 3.14 & 1.68 & 10 & 30 & 2.61 & 1.08 & 6 \\
\hline Mid-November/mid-December & 34 & 4.88 & 3.18 & 15 & 38 & 3.39 & 2.35 & 13 \\
\hline Mid-December/mid-January & 14 & 5.64 & 6.72 & 22 & 16 & 4.25 & 3.25 & 14 \\
\hline Mid-January/mid-February & 51 & 5.32 & 4.02 & 17 & 25 & 3.80 & 2.47 & 12 \\
\hline Mid-February/mid-March & 28 & 5.43 & 3.90 & 16 & 30 & 3.70 & 2.23 & 13 \\
\hline Mid-March/mid-April & 44 & 3.93 & 2.48 & 11 & 15 & 3.13 & 2.00 & 9 \\
\hline Mid-April/mid-May & 12 & 2.66 & 1.07 & 5 & 7 & 2.25 & 0.46 & 3 \\
\hline Mid-May/mid-June & 5 & 2.20 & 0.44 & 3 & 2 & 2.00 & 0.00 & 2 \\
\hline
\end{tabular}


percentage of solitary individuals occurred in spring-summer (Fig. 2). The proportion of deer in groups to solitary individuals, as well as group size, increased in autumn and remained high until mid-April (Fig. 2, Table 1). This trend was consistent for males and females, within each area (area A: $r_{\mathrm{S}}=0.89, p=0.003$; area $\mathrm{B}: r_{\mathrm{S}}=0.91, p=0.003 ; n=12$ monthly periods for all correlations), as well as within the same sex, between areas (males: $r_{\mathrm{S}}=0.78, p=0.01$; females: $r_{\mathrm{S}}=0.85, p=0.005 ; n=12$ monthly periods). Group size was greater in area A than in area B (Fig. $2 ; p<0.001$ ).

\section{Discussion}

Among ungulates, small and selective forest feeders live solitary or in pairs and hide to avoid predators. In open areas, the formation of groups seems to improve survival (Jarman 1974). In roe deer, grouping has been directly related to habitat openness (Bresiński 1982, Maublanc et al. 1987, Cibien et al. 1989), thus matching Jarman's (1974) scheme.

As the percentage of forest is much lower in area B than in area A, larger group sizes could have been expected in the former than in the latter. Conversely, our results revealed a greater percentage of solitary deer in area B. This pattern has been maintained throughout nearly all the year (Fig. 2). The habitat structure in area B, with wood patches interspersed with open fields, provide permanent cover proximity for roe deer (Fig. 1), thus making unnecessary the formation of groups for antipredatory purposes. On the other hand, deer may have formed larger groups in area $\mathrm{A}$ than in area $\mathrm{B}$, because of the smaller proportion of open pastures in the former.

In both areas, males were more solitary than females. This has been described also for other roe deer populations (Bideau et al. 1983). It may be explained by mother-offspring ties permaining over the seasons, as well as by the territorial behaviour of males in spring-summer. As density and predation pressure in both areas were comparable, the more solitary behaviour of deer in area B could depend on the greater availability of open habitat in which to disperse, eg to feed, than that in area A.

The grouping of roe deer is consistent and seasonal in different European areas (Zejda 1978, Bideau et al. 1983, Maublanc et al. 1987). Seasonal variation of grouping patterns has been explained through local changes in food and shelter availability for this species (Bresiński 1982, Bideau et al. 1983). Other authors have suggested that winter groups may play a social role by allowing males and females to meet each other and develop individual recognition, which later may lead to mating and to establish a hierarchy between males (Maublanc et al. 1987). Grouping in autumn-winter is likely to be primed by a decrease in levels of aggression, especially of males (Maublanc et al. 1987). No detectable food shortage occurred throughout our study, which in turn probably decreased potential 
competition in the cold season, when the territorial/mating period is over. As roe deer were significantly more solitary and groups smaller in the area with the greater proportion of open fields (area B), habitat openness is apparently not enough to determine aggregation in these deer. We conclude that the pattern of cover distribution could also be a key-factor to influence grouping.

Acknowledgements: We thank D. Baruffaldi, L. Bindi, the landowners and R. Mazzoni della Stella for their invaluable help. Two anonymous referees improved this report with helpful comments and advice. Our study has been financially supported by the Regional Government of Tuscany (Agricoltura, Caccia e Pesca), the programme "Human Capital and Mobility" of the European Union and the Italian Ministry for University and Research (MURST 60\%).

\section{References}

Bideau E., Vincent J. P. and Maire F. 1983. Evolution saisonniere de la taille des groupes chez le chevreuil en milieu forestier. Revue d' Ecologie (Terre Vie) 37: 161-169.

Bideau E., Vincent J. P. and Maublanc M. L. 1985. Organisation spatiale et sociale d'une population de chevreuil en falible densité. XVIIth Congress International Union of Game Biologists, Brussels: $17-21$.

Bresiński W. 1982. Grouping tendencies in roe deer under agrocenosis conditions. Acta Theriologica 27: 427-447.

Cibien C., Bideau E., Boisaubert B. and Maublanc M. L. 1989. Influence of habitat characteristics on winter social organisation in field roe deer. Acta Theriologica 34: 219-226.

Dzięciołowski R. 1979. Structure and spatial organization of roe deer populations. Acta Theriologica 24: $3-21$

Geist V. 1974. On the relationship of social evolution and ecology in ungulates. American Zoologist 14: 205-220.

Hald A. 1967. Statistical theory with engineering applications. Wiley, New York: 1-182.

Hoffmann G. 1976. Méthodes de recensement des populations de cerf (Cervus elaphus) et chevreuil (Capreolus capreolus). Bulletin de l'Office National de la Chasse 2: 3-34.

Jarman P. 1974. The social organisation of antelopes in relation to their ecology. Behaviour 48: 215-267.

Krebs C. J. 1989. Ecological methodology. Harper-Collins, New York: 1-654.

Kurt F. 1968. Das Sozialverhalten des Rehes. Mammalia Depicta. Paul Parey, Berlin: 1-84.

Maublanc M. L., Bideau E. and Vincent J. P. 1987. Flexibilité de l'organisation sociale du chevreuil en fonction des characteristiques de l'environnement. Revue d' Ecologie (Terre Vie) 42: 109-133.

Putman R. 1988. The natural history of deer. Christopher Helm (Publishers) Ltd., Kent: 1-191.

Ratcliffe P. R. and Mayle B. A. 1992. Roe deer biology and management, Forestry Commission Bulletin 105, HMSO, London: 1-28.

Vincent J. P. and Bideau E. 1992. Influence of density on spatial and social organization of forest roe deer (Capreolus capreolus L. 1758). [In: Ungulates '91. F. Spitz, G. Janeau, G. Gonzalez and S. Auglanier, eds]. S.F.E.P.M.-I.R.G.M., Paris-Toulouse: 267-269.

Zejda J. 1978. Field groupings of roe deer Capreolus capreolus in a lowland region. Folia Zoologica 27: 111-122.

Received 8 February 1996, accepted 6 March 1997. 